\title{
Understanding the Interrelationship Between Culture of Quality, Employee, and Organizational Performance
}

\author{
Vikas Kumar \\ Faculty of Accounting, Ton Duc Thang University, Ho Chi Minh City, Vietnam \\ Bristol Business School, University of the West of England, Bristol, UK \\ E-mail: Vikas.Kumar@tdtu.edu.vn (Corresponding Author) \\ Yu Han \\ Warwick Manufacturing Group, University of Warwick, Coventry, UK \\ E-mail: rainh22@126.com \\ Ngân Tuyết Trương \\ RMIT University Vietnam, Ho Chi Minh City, Vietnam \\ E-mail: ngan.truongthituyet@ rmit.edu.vn \\ Nhu Y Ngoc Hoang \\ School of International Business-Marketing, \\ University of Economics Ho Chi Minh City, Vietnam \\ E-mail: yhnn@ueh.edu.vn \\ Arvind Upadhyay \\ Brighton Business School, University of Brighton, Brighton, UK \\ E-mail: A.Upadhyay@brighton.ac.uk
}

\begin{abstract}
Culture of Quality (COQ) is regarded as an important component of total quality management (TQM) however this is a relatively new emerging theme, compared to other concepts in the quality management domain. As a result, literature resources on this topic are relatively scarce and there is a lack of empirical validation of the COQ framework. This study therefore attempts to fill this research gap and aims to empirically investigate the dimensions of the COQ and their impact on organisational and employee performance. The study also explores the interrelationship between each dimension of COQ. A set of hypotheses are proposed and empirically tested based on the 120 survey responses mostly from the Asian region. The survey data was analysed using SPSS through descriptive analysis, reliability analysis, correlation analysis and regression analysis. Findings show that COQ dimensions; leadership emphasis, message credibility, peer involvement and employee ownership encourage better employee performance. The study further suggests that organisations should work on ensuring supervision from top to bottom, accelerating information flow, creating autonomous working environment and getting staff involved in strategic management. In addition, findings show that COQ factors also interact with each other in varying degrees. The study therefore addresses an important research gap by empirically investigating the $\mathrm{COQ}$ dimensions and suggesting that from an employee perspective, organizational performance can be accelerated through quality culture management.
\end{abstract}

Keywords: culture of quality, leadership emphasis, message credibility, peer involvement, employee ownership, empirical study

\section{INTRODUCTION}

In the competitive business landscape organisations are facing cutthroat competition for their survival. Several factors contribute to the successful functioning of an organisation such as top management support, leadership, organisational culture, human resources, operational processes and financial stability. A great deal of work has been done in understanding the role of organisational culture in success of an organisation and several researchers have acknowledged this in their research studies (Elsmore, 2017).

It is increasingly evident that top management must have an explicit focus on the development and maintenance of their organization's culture (Gore, 1999). In recent years the COQ (Culture of Quality) has emerged as a popular topic (Kurey, 2014; Tejaningrum 2016). Many firms have utilized some method of quality management in order to control their quality alongside other indicators of performance (Gambi et al., 2015). However, there exists the fact that the intended results are not always produced by quality management initiatives (Harari, 1993; Beer, 2003; Asif et al., 2009). Thus, several companies' recent emphasis on enhancing their own quality goals has yet to achieve complete effectiveness; a commitment to a range of cultural factors 
such as companywide collective values, leadership, universal behaviors, a convincing vision and matching performance metrics and motivators is required to reveal a true culture of quality. To illustrate how a true culture of quality could increase company effectiveness, investigating influencing factors on employee's performance is significant. For example, employees effectively and efficiently utilizing organization resources to achieve objectives (Daft, 2000), or employees play a crucial role in determining continuous improvement (Nasab et al., 2014). It could be said that one of the most critical and decisive mechanisms in establishing the status of an organization in relation to quality, is the performance of its employees.

Gore (1999) compared the organizational culture with TQM and indicated that "people believe organizational culture is essential to the success of an organization in a long period. It is obvious that leadership should pay precise attention to the development and stability of the organizational culture. Managers need to think about the culture that has been generated. Several studies have mentioned TQM as an integrated effort to attain and sustain the high quality of products based on the maintenance of continuous process improvement and error prevention at all levels and in all functions of the organization (Flynn, et al., 1994; Petliushenko, et al., 2018). It is also an important mechanism to support the organization achieving higher profits (Shenawy, 2007) as well as their competitive advantages in markets (Tena et al., 2001). However, Sabella, Kashou and Omran, (2014) found that most of time, the successful execution of TQM could not match operational performance improvement. Gore (1999) came up with the idea that TQM provides a framework for building an organizational culture that will equip an organization to continuously learn and improve. Whereas Alotaibi (2014) points at the importance of working with employees to ensure commitment at the top and being customer centric. Alotaibi (2014) also regarded quality culture as one of the most crucial points to improve organizational competitiveness as he showed that all TQM factors have a significant relationship with quality culture. In the same year Srinivasan and Kurey (2014) defined a 'true culture of quality' through a wide range of interview investigation. They pinpointed four factors that drive quality as a cultural value: leadership emphasis, message credibility, peer involvement, and employee ownership of quality issues.

Several research attribute Tejaningrum, Azis, and Irjayanti (2016)'s creation of a quality culture model for small and medium companies. Tejaningrum (2016) research focused on how process capability and quality culture influence each other. Although the concept of quality management has been studied for quite a long period, the existing research about creating a culture of quality is insufficient (Kurey, 2014; Tejaningrum, 2016). This study is therefore motivated with growing prominence of culture of quality and associated research gaps. The study attempts to empirically validate the culture of quality model proposed by Srinivasan and Kurey (2014) and explore its relationship with employee and organizational performance.

Rest of the paper is organized as follows. Section 2 presents an overview of the conceptual underpinning starting with historical development of quality management,
TQM and then moving on to the dimensions of culture of quality, employee performance and organizational performance. Section 3 presents the research methodology followed in this study together with the data collection process. Section 4 presents the findings of the study and finally Section 5 concludes the study.

\section{THEORETICAL FRAMEWORK DEVELOPMENT}

\subsection{History of Quality Management}

Organizational culture has long been acknowledged to be important to the success of an organization. It is increasingly evident that top management must have an explicit focus on the development and maintenance of their organization's culture (Gore, 1999). Gore (1999) indicated in their study that specific elements of culture were stronger in organizations practicing TQM than where there had been a reengineering effort. The study also suggested that there was more likelihood of success where these cultural elements were present. The links between culture and performance, and specifically success with improvements, deserve additional research. Cameron and Sine (1999) introduced a framework of organizational quality culture in the study. It was explained to be generated due to failure regarding quality initiatives and vague connection with effectiveness. According to Irani, Beskese and Love (2004), many researchers, if not all, agree that Total Quality Management is somehow linked to organisational culture. The term 'Total Quality Culture' is frequently used in the literature, but there still exists a disagreement on whether TQM involves changing a culture to achieve total quality or whether it means using the existing culture. Roldán, LealRodríguez, and Leal (2012) also mentioned this quality culture typology and quoted 'the quality culture of an organization is a subset of an organization's overall culture. It reflects the general approach, the values, and the orientation towards quality that permeate organizational actions. The key advantage of treating quality as a cultural variable is that the ambiguity associated with the multiple definitions and dimensions of TQM diminish.'

However, through research of ethical leadership in organizations, Bachmann (2017) found that recent concern in some operating machine factories was concluded as 'Speed is more important than quality', rather than the traditional pursuit of perfect quality. Bachmann (2017) later indicated that it was the wrong idea for workers as well as for leaders.

\subsection{Total Quality Management (TQM)}

Total Quality Management (TQM) is interpreted in several ways. According to Ahire et al. (1996) TQM was viewed as a multidimensional construct. Principally identifying dimensions of quality information, continual improvement, leadership, process control, and teamwork. There are initiatives generally described as a part of a TQM effort that directly lead to creating a culture with very specific characteristics that support change and improvement. These initiatives as outlined in the Baldrige Criteria include: participative management and openness (supported by encouraging employee involvement, 
empowerment, the use of teams, education and training, and extensive communication), a rational approach (fact based decision making, clear mission, objectives, statistical tools and statistical process control, evaluation and improvement cycles, etc.), flexibility (customer focus, continuous improvement), and integrity (emphasis on values, public responsibility) (Gore, 1999). Despite TQMs' hypothetical assurance, there have been some investigations that have found application is frequently unsuccessful (Douglas and Judge, 2001). Eskildson (1994) reveals that the TQM tool has either indeterminate or undesirable influences on organization's performance and employee's performance. Studies showed that within 18-24 months into the project TQM has a high failure rate (Smith et al., 1993). The reason for failure of TQM might be the cultural position of the company influencing consistency in application with the organizational culture (Dean and Evans, 1994). There could be four different cultures that cause challenges when applying TQM including clan culture, adhocracy culture, hierarchical culture, and market culture. According to the study of $\mathrm{Rad}$ (2006), the reasons for failure of TQM implementation include lack of formalized strategy for changing plans; lack of employee motivation; lack of enhancing and preserving quality focused culture; and missing link between salary and organization performance. Gore (1999) however believed that TQM can create a culture and it is that aspect of TQM that managers must focus on. Rad (2006) found that TQM reflects customer satisfaction through focus on an organisation's culture and attitude. Whereas Kaluarachchi (2010) found that the success of TQM is strongly related to supportive culture in the Sri Lankan case study. In general, TQM is not appropriate in all types of culture. It is not a one size fits all situation. Even though culture is inimitable to each company (Trought, 1995), it is generally acknowledged that there are certain elements that commonly define culture of quality in all types of workplace. There has been a shift in the interest of researchers towards creating a culture of quality recently. The upcoming sections would explore this in more detail.

\subsection{Culture of Quality (COQ)}

House and Javidan (2004:15) state culture as "shared motives, values, beliefs, identities, and interpretations or meanings of significant events that result from common experiences of members of collectives that are transmitted across generations". Considering the diversity of cultures, Moran et al. (2014) found that it is challenging to determine the major belief theme of people and other aspects influencing their attitudes and performances. GimenezEspin et al. (2013) state that organizational culture plays a crucial role in assisting the supported adoption of business strategies. However, it can be argued that norms and values of a national culture are mostly likely to influence organizational culture (Stewart, 2010), and directly and indirectly affect employee behaviour (House and Javidan, 2004).

According to Ilies, Sălăgean and Beleiu (2017), a culture of quality (COQ) refers to orienting the organizational culture towards the TQM requests. Roldán, Leal-Rodríguez and Leal (2012) have made a similar point earlier that the more advanced quality culture are more related to the level of TQM programme performance than less advanced cultures, the latter presenting a negative influence of the culture archetype. Regarding the components of organizational culture, quality culture involves creating or changing, shaping the beliefs and values of the organization's members on the awareness that everyone must do things right the first time and every time, and that all the organizational activity must be improved continuously by involving each member of the organization in achieving and improving quality (Blouin, Tekian, \& Harris, 2019). The process of continuous improvement is reflected in the performance and the market competitiveness. These beliefs and values determine quality-oriented attitudes and behaviours, such as customer focus, accountability, and involvement in quality achievement.

Srinivasan and Kurey (2014) mentioned that under pressure from compressing cycle times and high error likelihood, managers must find a new approach to quality, which moves beyond the traditional 'total quality management' tools in the past. Tejaningrum (2016) also defined the concept of quality culture in former study: trust, action, thought patterns, values, habits, thought, believed and owned by members of the organization. Beliefs and values are reflected in the decision-making process, the behaviour of Human Resources, Environmental Management, Management of Engineering and artefacts, as well as the obsession with quality. As for the quality culture, there are four essential factors that are going to discuss below based on the work of Srinivasan and Kurey (2014).

\subsubsection{Leadership Emphasis}

Leadership is considered as one of the staple constructs and decisional components in organisations (Kuchinke, 1998). Srinivasan and Kurey (2014) indicate that leadership emphasis means that an ideal thinking of organizational culture usually begins in leadership if they want to convince their employees of quality importance. Dahlgaard and $\mathrm{Mi}$ Dahlgaard-Park (2006) also regarded leadership as one of the essences of TQM, lean production and Six Sigma. Leadership has the ultimate responsibility for setting the strategic direction and establishing systems that will facilitate high organizational performance. The leadership element has multiple dimensions: the creation of a unifying purpose, motivating change, managing the environment, and cultivating a participatory approach to improved performance (Sabella, Kashou and Omran, 2014). Ilies, Sălăgean, and Beleiu (2017) studied the impact of leadership on customer relationship in Romanian metal construction industry. They showed a strong positive correlation between the TQM system's components (leadership and quality culture) and customer relationship. Bachmann (2017) studied the pivotal role that ethical leadership or leadership culture played in organizations and answered the question about little change in business behaviour. These studies show that top management should act as a model in persisting quality.

\subsubsection{Message Credibility}

Message credibility is defined as an individual's opinion on the reliability of the content of communications. (Haigh and Brubaker, 2010). Generally, in an organization, message credibility is related to communication flows. Message features include message quality, message effectiveness, author credibility, and linguistic choices that 
may also influence the reader's perception of organisational credibility (Worthington et al., 2015). According to Srinivasan and Kurey (2014), smart leaders realize that quality messaging, like any campaign, needs to be updated constantly. Managers should regularly test messages with their employees and use the feedback to ensure sustained relevance. As for the importance of information flow, Barjot and Schröter (2014) indicated that all flow of information in groups with more than 20-30 people needs to be regulated; if this is not done, important information might not reach the appropriate persons in due time. The researchers believe that authority is a keystone in all organizations. It is expressed in upward and downward hierarchical steps. This bidirectional flow of information in organizations is a crucial characteristic: both streams must be investigated when an assessment is done. Perceptions of the source's trustworthiness could be affected by the addition of deceptive materials to the source of the information (McCroskey et al., 2002). Hubbell and Chory-Assad (2005) illustrate trustworthiness behaviours as keeping promises, connecting truthfully and directly, giving the truth, and not hurting others, etc. Nordback, Myers and McPhee (2017) have concluded that employees' perceptions about flexibility were linked to communication with supervisors and co-workers that shaped their agentive powers, behaviours, and relationships. Appelman and Sundar (2016) find that clarifying message credibility and its impacts on any contexts seem to make a remarkable contribution to an organisation's ability to improve quality.

\subsubsection{Peer Involvement}

Research studies have shown that teamwork has been considered as the backbone of many organisations (Hamilton et al., 2003). Team engagement has shown to increase the organisational efficiency. Srinivasan and Kurey (2014) took HGST (formerly Hitachi Global Storage Technologies) as an example to indicate that measures like organizing friendly quality competition and putting positive social pressure are useful for encouraging employees to generate quality initiatives. Effective teamwork and - more generally - team management are essential elements to consider in order to foster knowledge management and successful organizational learning processes (Vivas-López, 2014). It is the responsibility of managers to introduce teamwork given that it can enhance employee performance. The survey results show that the level of trust is higher among employees working in teams, sharing not only their tasks, but also the responsibility. Dahlgaard and $\mathrm{Mi}$ Dahlgaard-Park (2006) indicate that more and more traditional management activities must gradually be delegated to ordinary employees together with the necessary authority and capability (education and training) to plan, check and improve these activities (eliminate waste) to the benefit of themselves and the company. These evidence show that peer involvement is essential for driving quality initiatives successfully.

\subsubsection{Employee Ownership}

Research has shown that there has been an increase in a wide range of all-embracing worker-focused methods by organisations to heighten their competitive performance in markets for their products (Paauwe, 2004). Employee ownership has therefore emerged as a crucial factor in this process (Sengupta et al., 2007) and hence it is important to provide right level of guidance. Srinivasan and Kurey (2014) believed that one of the defining traits of an organization with a true culture of quality was that employees were free to apply judgment to situations that fell outside the rules. They also showed that employee ownership affects organizational productivity. Javed (2018) regards efficiency as a relative productive performance and showed that employees' participation in the decision-making process gives them sense of psychological ownership and align their interests with the organization. This leads in reduction of the organizational operating costs, improving the quality of organizational decision making, and reduction of the agency costs thus, resulting in overall improvement in organizational productivity. Ben-ner and Jones (1995) also showed that employee ownership impacts the productivity of the organisation. Kim and Patel (2017) using the sample from European firms showed that contextual factors, i.e., firm-related factors are important for the effective utilization of employee ownership. Oversmith (1990) however stated that developing true employee ownership of quality improvement is a process in itself, which requires sending clear signals to employees that management fully supports the process and is committed to making it successful.

Whatever the measure is, the aim of COQ study is to bring better performances of both employees and organizations. The next section therefore explores the impact of quality culture on employee and organisational performance.

\subsection{Employee Performance}

Many studies state that the high level of employee commitment plays a crucial role in improving their performance (Steers and Lee, 2017; Pierce et al., 1991). Wilson et al. (1990) reveal that employee commitment also affects other aspects for example, low labour turnover. Weitzman and Kruse (1990) demonstrated that unless individuals plan to work long term in the same organisation, the free-riding effects could not be minimal, and the profitsharing effect will probably not work on their motivation and performance. Furthermore, it is extensively claimed that the lower level of worker turnover positively forces firmspecific capital investment (Lincoln and Kalleberg, 1996). Thus, it leads to the greater enhancement of labour productivity and successively superior financial performance. Kristianto and Rivai (2018) consider that improvement of the company's internal condition through human resources aims to strengthen and enhance the existence of companies in the face of local and global competition that will be more stringent. This means the company must improve the performance of the company by improving the performance of its employees. The development of the company cannot be separated from the role of each of the human resources in it. Factors of quality culture contribute to the intensification of employee performance. Ismiyarto et al. (2015) indicate that a strong organizational culture will affect all members of the organization to work motivated and behave shown to the satisfaction of working to produce daily performance in 
order to achieve organizational goals have been set as the meaning and significance of bureaucratic reform. According to Grant and Hofmann (2011), ideological messages are typically delivered by leaders, but employees may be suspicious of ulterior motives-leaders may merely be seeking to inspire higher performance, although ideological messages are thought to inspire employee performance. In most cases, employee performance leads to organizational performance, directly or indirectly. For example, Hatane (2015) found in their study that employee satisfaction and employee performance are able to positively intervene in the relationship of the learning organisation to financial performance. Awadh and Alyahya (2013) however assert that the performance of employees improves by establishment of strong culture of an organization.

\subsection{Organisational Performance}

Organisational performance has been studied by many researchers (Al-kalouti et al., 2020; Kim and Patel, 2017). Within the strategic human capital perspective, employee ownership has been widely studied through the lenses of agency theory, property rights, and resource-based view (RBV). These theoretical frameworks propose that employee ownership improves employees' effort and motivation which consequently enhance organisational performance (Kim and Patel, 2017). The high-quality relationship between a leader and followers enable a better comprehension of dyadic issues and enable both parties to easily tackle them, which would result in better performance, not only from the individual subordinates, but would result in better performance throughout the organization. O'Boyle, Patel and Gonzalez-Mulé (2016) found that employee ownership has a small, but positive and statistically significant relation to organisational performance and the interest in the employee ownership and its impact on performance has increased in studies over years. Lo et al. (2015) recognized that rapport between leaders, followers, and market orientation are the key elements in understanding the important constituents that influence organisational performance. According to Stanić, Miklošević, and Glavaš (2017), teamwork could be a key driving force for organizational performance. The culture and performance have been interrelated to each other based upon perfect association between business processes (Awadh and Alyahya, 2013; Reichers and Schneider, 1990). Khan and Nadeem (2016) showed that quality practices improve organisational performance. As it is evident that there has been attempts to explore the quality and organisational performance relationship however, research exploring the impact of quality culture on organizational performance is limited and demands further investigation.

\subsection{Research Gap}

Quality management has been a very popular topic of attention for researchers across the globe. However, this interest in recent years have shifted in the direction of creating a culture of quality. A study on culture of quality by
Srinivasan and Kurey (2014) ignited this discussion further when they proposed culture of quality as a multidimensional which has been largely treated as a single dimensional construct. In recent years a number of studies such as Tejaningrum (2016) and Tejaningrum, Azis, and Irjayanti, (2016) have attempted to explore culture of quality issues. However, there is still lack of studies that have attempted to empirically validate the culture of quality framework. Most of the studies have so far explored quality management in wider context, such as the origins of TQM, the relations between quality management and other factors. For example, Baird, Jia Hu and Reeve (2011) discussed about the relationships between organizational culture, total quality management practices and operational performance. Whereas, Budacia (2015) studied organizational culture as an instrument of the quality management within commercial firms.

To sum up, Srinivasan and Kurey (2014) believed there are various specific actions needed to help an organization shift from a rules-based quality environment to a true culture of quality in different companies. However, the first step in the process will always be the same: Managers must decide that a culture of quality is worth pursuing. As a result, a culture of quality requires the interactions among these essentials above. It also requires employees to apply skills and make decisions in highly ambiguous but critical areas while leading them toward deeper reflection about the risks and payoffs of their actions. In an environment where customers' tolerance for quality problems is declining, a workforce that embraces quality as a core value is a significant competitive advantage (Srinivasan and Kurey, 2014). However, there is insufficient literature directly related to the dimensions of quality culture. Furthermore, it is not well explored how culture of quality affects employee performance. This study therefore proposes following conceptual framework and a set of hypotheses derived from the literature which will be empirically validated through the survey data.

Based on the discussion presented in previous sections and the conceptual framework (See Figure 1) following hypotheses are generated:

H1: A greater emphasis on leadership affects the employee performance positively

H2: A greater emphasis on leadership has a positive impact on organizational performance

H3: Improving message credibility will positively impact employee performance

H4: Improving message credibility will positively impact organizational performance

H5: Peer Involvement will have a positive impact on employee performance

H6: Peer Involvement will affect organizational performance positively

H7: Employee Ownership will positively influence employee performance

H8: Employee Ownership will positively influence organizational performance 


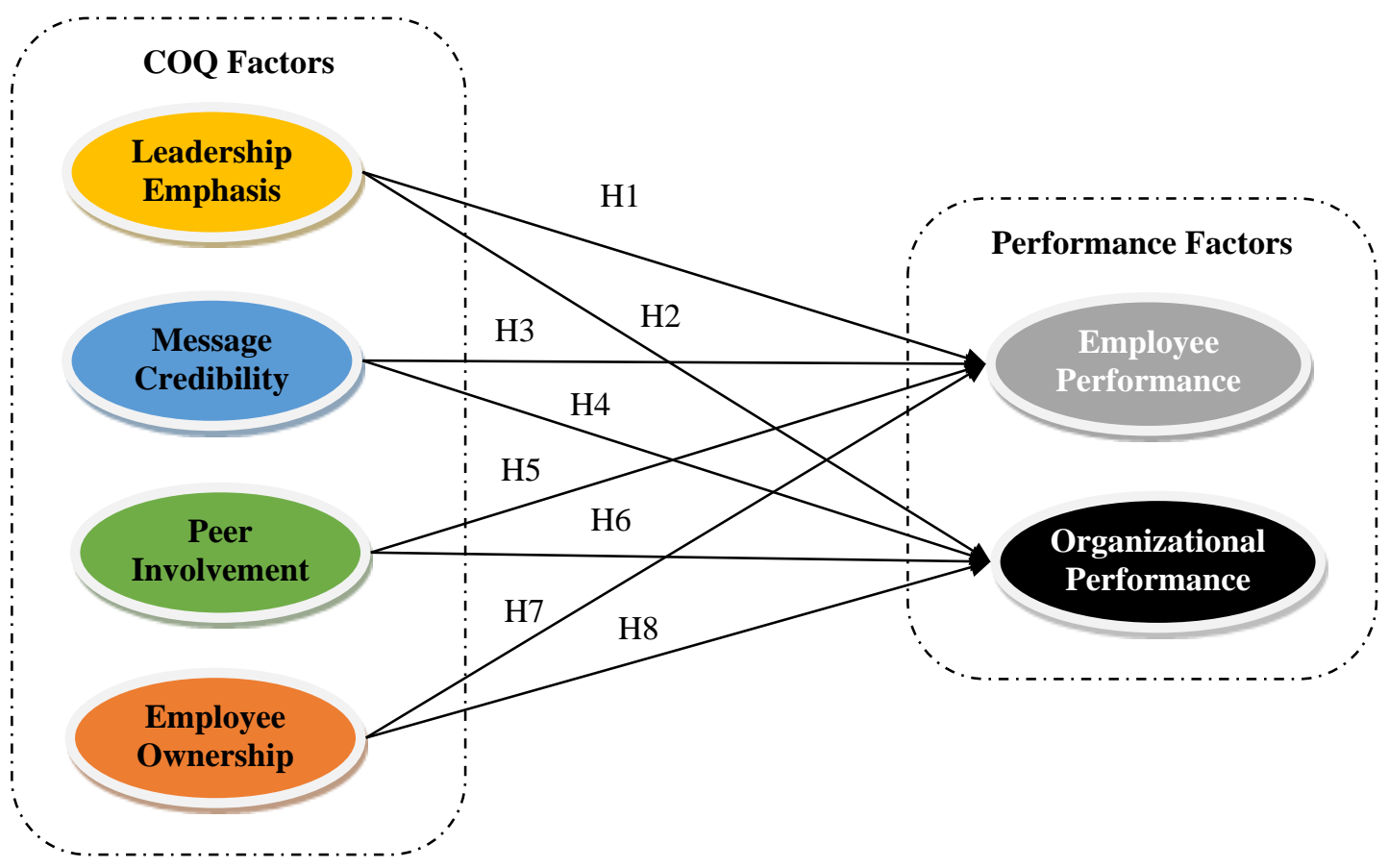

Figure 1 Conceptual framework

\section{METHODOLOGY}

Based on the study of Srinivasan and Kurey (2014), leadership emphasis, message credibility, peer involvement and employee ownership are set to be four dimensions to be investigated in the research. Thus, a survey design was adopted to explore the interrelationship between quality culture dimensions and its impact on employee as well as organizational performance. The online survey was created using Qualtrics and distributed via an anonymous link to more than 400+ respondents who were either CEOs, senior managers, quality managers or someone with quality management experience identified using LinkedIn, Facebook, direct personal contact and snowballing technique. The survey questionnaire consisted of six parts. The first part included three questions on personal information whereas rest of the survey was divided into five parts, including leadership emphasis, message credibility, peer involvement, employee ownership, and employee performance and organizational performance. Data from the survey was exported to Excel and SPSS for further analysis. The study employs descriptive analysis, correlations and regressions to analyse the data. In this research, dependent variables refer to employee performance and organizational performance, while independent variables refer to the four quality culture dimensions.

\section{FINDINGS}

The survey was distributed to more than 400+ respondents. The distribution of questionnaire resulted in 134 responses over the span of a month and two reminders a week apart before the survey was closed. Thus, resulting in a response rate of $33.5 \%$ that is considered a good response rate. The careful evaluation of the responses revealed that 14 responses were partially incomplete. These responses were therefore deleted from the sample which resulted in a final sample size of 120 responses. This resulted in effective survey response rate of $30 \%$. The data demographics showed that majority of respondents $(92.50 \%)$ were from Asia, 5\% were from Europe, $0.83 \%$ from North America, $0.83 \%$ from South America and $0.83 \%$ from Australia. Most of the respondents did not specify where country they belong to as this was an optional part of the questionnaire. However, those who did respond to were primarily from China. In terms of their position $8 \%$ were CEOs, 18\% were Senior Managers, 16\% Quality Managers, and $54 \%$ General Employees whereas $4 \%$ did not specify their positions within their organisations. Regarding the size of the organisations, $54.17 \%$ of participants work for companies with over 250 employees. Around $9.17 \%$ of participants were working for companies with 101-250 employees, while $15 \%$ for companies employing 51-100 employees and $21.67 \%$ respondents were from companies employing less than 50 people. So essentially, $54.17 \%$ respondents came from large organisation whereas $45.83 \%$ respondents came from Small and Medium Enterprises (SMEs).

Respondents were then asked about their level of awareness about the TQM and around $56.67 \%$ of respondents were well familiar with the term however interestingly $43.33 \%$ respondents said 'No'. TQM has been practiced for decades however the result does not show an optimistic view of the quality awareness. As majority of the respondents are from Asia this is an interesting finding given that quality management originated in Asia. It indicates that in many organizations in the Asian region, quality 
management is still not very well established or communicated among employees. However, this is not completely surprising as several developing countries in the region have just embarked on the quality management journey. The findings further revealed that around $82.50 \%$ of respondents believed the combination of top management supervision and employee consciousness is the best way to establish a culture of quality. However, only $3.33 \%$ of respondents' regard top management supervision as a more effective way whereas $14.17 \%$ of respondents expressed that they are more likely to increase the COQ awareness of their own.

As multiple indicators were used to measure the five variables (leadership emphasis, message credibility, peer involvement, employee ownership, and employee performance) except the organisational performance, for reliability analysis, Cronbach's alpha test was carried out. Table 1 shows the reliability analysis results. All the measures met the threshold Cronbach's Alpha value of .70 which point to the relative consistency and stability of the constructs

Table 1 Reliability analysis

\begin{tabular}{|l|c|c|}
\hline \multicolumn{1}{|c|}{ Variables } & No. of Items & Cronbach Alpha Value \\
\hline Leadership Emphasis & 4 & .801 \\
\hline Message Credibility & 2 & .701 \\
\hline Peer Involvement & 4 & .707 \\
\hline Employee Ownership & 4 & .817 \\
\hline Employee Performance & 3 & .705 \\
\hline
\end{tabular}

After confirming reliability of the constructs, correlation analysis was conducted to test the hypotheses. The findings of the correlation analysis is shown in Figure 2. Generally, studies regard Pearson correlation values between $0.000<\mathrm{r}<0.300$ as a weak correlation, $0.300<\mathrm{r}<0.500$ as a low correlation and $0.500<\mathrm{r}<0.800$ as a moderate correlation. Correlation analysis finding shows that all variables are significantly correlated with each other. H1 stated that 'A greater emphasis on leadership affects the employee performance positively', our findings indicate a moderately significant correlation between these variables confirming our first hypothesis. Similarly, our findings show support for $\mathrm{H} 2$ as correlation between leadership emphasis and organisational performance was positively correlated (0.309). Correlation between message credibility and employee performance was also positive and moderately significant (0.511) thus supporting H3. Similarly, message credibility and organisational performance was also found to be positively correlated ( 0.361$)$ confirming H4. Correlation analysis also confirmed rest of the hypotheses (H5-H8) as it showed there is a positive correlation between all the variables. The findings showed a moderate and positive correlation between peer involvement and employee performance (0.591) (H5). Peer involvement and organisational performance was weakly correlation (0.197) (H6). Employee ownership and employee performance was moderately correlated (0.649) (H7) whereas and a low correlation (0.392) was found between employee ownership and organisational performance (H8). Thus, the findings support all the proposed hypotheses.

In order to further verify the findings of the correlation analysis, regressions were carried out. Regression analysis showed that leadership emphasis, message credibility, peer involvement and employee ownership altogether explain around $19.2 \%$ of variance of organisational performance (Table 2). ANOVA analysis shows that model was significant (Table 3). Table 4 presents the coefficients of the model and shows that coefficients for message credibility and employee ownership were significant thus showing that these variables predict the change of organisational performance. It was interesting that leadership emphasis and peer involvement were not found to be significant. 


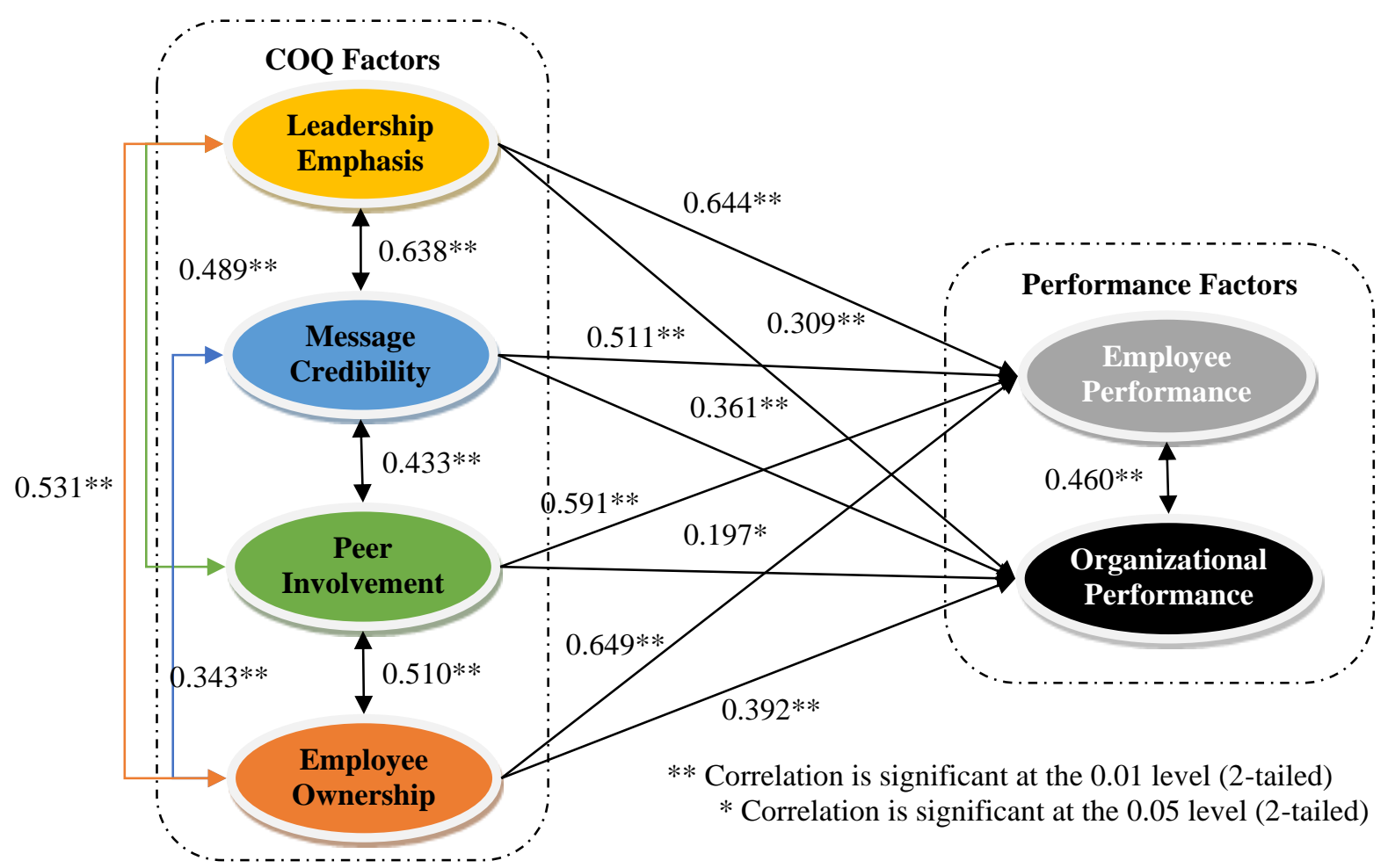

Figure 2 Correlation analysis

Table 2 Regression analysis for organisational performance

\begin{tabular}{|c|c|c|c|c|}
\hline Model & $\mathbf{R}$ & R Square & $\begin{array}{l}\text { Adjusted R } \\
\text { Square }\end{array}$ & $\begin{array}{c}\text { Std. Error of the } \\
\text { Estimate }\end{array}$ \\
\hline 1 & $.468 \mathrm{a}$ & .219 & .192 & .551 \\
\hline
\end{tabular}

Table 3 ANOVA analysis for organisational performance

\begin{tabular}{|c|c|c|c|c|c|c|}
\hline & Model & $\begin{array}{c}\text { Sum of } \\
\text { Squares }\end{array}$ & df & $\begin{array}{c}\text { Mean } \\
\text { Square }\end{array}$ & $F$ & Sig. \\
\hline \multirow{3}{*}{1} & Regression & 9.827 & 4 & 2.457 & 8.078 & $.000 \mathrm{~b}$ \\
\hline & Residual & 34.973 & 115 & .304 & & \\
\hline & Total & 44.800 & 119 & & & \\
\hline
\end{tabular}

Table 4 Coefficients for organisational performance

\begin{tabular}{|c|c|c|c|c|c|c|}
\hline & \multirow[t]{2}{*}{ Model } & \multicolumn{2}{|c|}{$\begin{array}{l}\text { Unstandardized } \\
\text { Coefficients }\end{array}$} & \multirow{2}{*}{$\begin{array}{c}\text { Standardized } \\
\text { Coefficients } \\
\text { Beta }\end{array}$} & \multirow[t]{2}{*}{$t$} & \multirow[t]{2}{*}{ Sig. } \\
\hline & & B & Std. Error & & & \\
\hline \multirow{5}{*}{1} & (Constant) & 2.632 & .421 & & 6.257 & .000 \\
\hline & Leadership & -.003 & .025 & -.016 & -.134 & .894 \\
\hline & Message & .093 & .034 & .295 & 2.709 & .008 \\
\hline & Peer & -.032 & .032 & -.103 & -1.007 & .316 \\
\hline & $\begin{array}{l}\text { Employee } \\
\text { Ownership }\end{array}$ & .067 & .020 & .352 & 3.398 & .001 \\
\hline
\end{tabular}

a. Dependent Variable: Org_Perf
Further regression analysis showed that leadership emphasis, message credibility, peer involvement and employee ownership altogether explain around $58.2 \%$ of the variance for employee performance (Table 5). ANOVA analysis shows that model was significant (Table 6). Table 7 presents the coefficients of the model and shows that coefficients for leadership emphasis, peer involvement and employee ownership were significant thus showing that these variables predict the change in employee performance. It was interesting that message credibility was found not to be significant which is in contrast to its impact on organisational performance.

Table 5 Regression analysis for employee Performance

\begin{tabular}{|c|c|c|c|c|}
\hline Model & $\mathbf{R}$ & R Square & $\begin{array}{c}\text { Adjusted R } \\
\text { Square }\end{array}$ & $\begin{array}{l}\text { Std. Error of the } \\
\text { Estimate }\end{array}$ \\
\hline 1 & $.772 a$ & .597 & .582 & 1.35573 \\
\hline $\begin{array}{l}\text { a. } \\
\text { b. }\end{array}$ & $\begin{array}{l}\text { Predictor } \\
\text { Leadersh } \\
\text { Depende }\end{array}$ & onstant), & & \\
\hline
\end{tabular}

Table 6 ANOVA analysis for employee performance

\begin{tabular}{ll|c|c|c|c|c}
\hline \multicolumn{2}{l|}{ Model } & $\begin{array}{c}\text { Sum of } \\
\text { Squares }\end{array}$ & df & $\begin{array}{c}\text { Mean } \\
\text { Square }\end{array}$ & F & Sig. \\
\hline \multirow{3}{*}{1} & Regression & 312.497 & 4 & 78.124 & 42.505 & $.000 \mathrm{~b}$ \\
\cline { 2 - 7 } & Residual & 211.370 & 115 & 1.838 & & \\
\cline { 2 - 7 } & Total & 523.867 & 119 & & & \\
\hline
\end{tabular}

a. Dependent Variable: Employee Performance

b. Predictors: (Constant), Employee Ownership, Message, Peer, Leadership 
Table 7 Coefficients for employee performance

\begin{tabular}{|c|c|c|c|c|c|c|}
\hline & \multirow{2}{*}{ Model } & \multicolumn{2}{|c|}{$\begin{array}{l}\text { Unstandardized } \\
\text { Coefficients }\end{array}$} & \multirow{2}{*}{$\begin{array}{c}\text { Standardized } \\
\text { Coefficients } \\
\text { Beta }\end{array}$} & \multirow{2}{*}{$t$} & \multirow{2}{*}{ Sig. } \\
\hline & & B & $\begin{array}{l}\text { Std. } \\
\text { Error }\end{array}$ & & & \\
\hline \multirow{5}{*}{1} & (Constant) & -.172 & 1.034 & & -.167 & .868 \\
\hline & Leadership & .193 & .061 & .272 & 3.153 & .002 \\
\hline & Message & .128 & .084 & .119 & 1.519 & .131 \\
\hline & Peer & .245 & .078 & .230 & 3.123 & .002 \\
\hline & $\begin{array}{l}\text { Employee } \\
\text { Ownership }\end{array}$ & .226 & .049 & .347 & 4.659 & .000 \\
\hline
\end{tabular}

a. Dependent Variable: Employee Performance

\section{SUMMARY, DISCUSSIONS AND CONCLUSION}

This study empirically investigated the interrelationship between the culture of quality dimensions and its impact on employee and organisational performance. The four dimensions of COQ are based on Srinivasan and Kurey's (2014) work on creating a culture of quality. To expand their research, eight hypotheses (H1-H8) were proposed and tested in this study. The data for the study was collected using a survey-based approach and findings are presented based on 120 valid responses.

A comprehensive understanding of COQ theory has been reviewed and the most significant contribution is enriching the meaning and depth of COQ theory. The literature review identified the four dimensions of culture of quality. The study contributes to the limited research on COQ and provides empirical validation of the COQ framework proposed by Srinivasan and Kurey's (2014). Through the survey, the relationship between each of these dimensions of culture of quality and how they affect the performance of enterprises were investigated. The study found that quality of culture factors not only affect organisational performance and employee performance, but also influences each other internally and mutually. This goes against what Beer (2003) indicated that to achieve reliable quality outcomes, TQM requires that employees follow standardized methods. As a result, employees undoubtedly experience a loss of freedom and increased control. What our study suggested was giving more autonomy to employees to positively influences company performance. Most of the researchers focused on teamwork as a similar topic to peer involvement. This study drew people's attention to this factor and helped participants update their understanding.

The study has an important theoretical and practical implications. From theoretical perspective this study has a very important reference value for COQ development, especially the implementation of a COQ ideology. This is one of the first studies to empirically validate the framework proposed by Srinivasan and Kurey's (2014). Since leadership emphasis, message credibility, peer involvement and employee ownership are found to encourage better employee performance, organizations should work on ensuring supervision from top to bottom, accelerating information flow, creating autonomous working environment, and getting staff involved in strategic management. After all, better individual achievement leads to satisfying organisational performance. Our research findings also strongly recommend that companies should improve their performance by making good use of the COQ factors. If companies realize the interrelationship between COQ factors, they could make progress by either pushing each factor or letting them work mutually. For example, sometimes a company might not think of integrating leadership and peer involvement as one target, letting powerful leadership accelerate great peer involvement and vice versa, when it takes repeated measures to strengthen both two factors respectively. In fact, the two different ways lead to the same result, that is, better organisational performance. With a good top management, employee ownership will be strengthened, and updated information will be delivered. Meanwhile, employees will be willing to take part in building a culture of better quality. All of the factors hence lead to a healthily growing company.

There are some limitations with this study. The findings are based on only 120 valid survey responses mostly from the Asian region. The study would benefit in the future by having a broad array of responses from various regions. Increased survey responses would also add to the generalisability of the findings. Having a cross comparison between the regions (for example, developed and developing regions) will help to tease out the differences. It would be interesting to see how COQ relationship varies under regional and cultural diversity. Therefore, in future studies use of expert interviews in conjunction with the survey will further enhance the credibility of the findings.

\section{REFERENCES}

Al-kalouti, J., Kumar, V., Kumar, N., Garza-Reyes, J. A., Upadhyay, A., \& Zwiegelaar, J. B. (2020). Investigating innovation capability and organizational performance in service firms. Strategic Change, 29(1), pp. 103-113.

Alotaibi, F.M.S., (2014). Impact on quality culture of total quality management practices factors. International Journal of Business and Economic Development, 2(3), pp. 35-48.

Appelman, A., \& Sundar, S. S. (2016). Measuring message credibility: Construction and validation of an exclusive scale. Journalism \& Mass Communication Quarterly, 93(1), pp. 59-79.

Asif, M., de Briijn, E. J., Douglas, A. \& Fisscher, O. A. M. (2009). Why quality management program fail? A strategic and operations management perspective. International Journal of Quality \& Reliability Management, 26(8), pp. 789-814.

Awadh, A. M., \& Alyahya, M. S. (2013). Impact of organizational culture on employee performance. International Review of Management and Business Research, 2(1), pp. 168-175

Bachmann, B., (2017). Ethical Leadership in Organization: Concepts and Implementation, Springer, Cham, pp. 1203

Baird, K., Jia Hu, K., and Reeve, R. (2011). The relationships between organizational culture, total quality management practices and operational performance. International Journal of Operations \& Production Management, 31(7), pp. 789-814.

Barjot, D. and Schröter, H.G., (2014). The flow of information in organizations. Organizational theories 
as tools for business history. Entreprises et histoire, (2), pp. 6-23.

Beer, M. (2003). Why total quality management programs do not persist: the role of management quality and implications for leading a TQM transformation. Decision Sciences, 34(4), pp. 623-642.

Beer, M., (2003). Why total quality management programs do not persist: the role of management quality and implications for leading a TQM transformation. Decision Sciences, 34(4), pp. 623-642.

Blouin, D., Tekian, A., and Harris, I. B. (2019). Do organizational cultures of Canadian medical schools promote a quality culture? Medical Teacher, 41(6), pp. 662-667.

Budacia, E. A. (2015). Organizational culture as an instrument of the quality management within commercial firms. Romanian Economic and Business Review, 10(1), pp. 40-49.

Cameron, K. and Sine, W., (1999). A framework for organizational quality culture. Quality Management Journal, 6(4), pp. 7-25.

Daft, R. I. (2000), Organisational Theory and Design, 7th ed. South-Western College Publishing, Thomson Learning, pp. 700

Dahlgaard, J. J., and Mi Dahlgaard-Park, S. (2006). Lean production, six sigma quality, TQM and company culture. The TQM magazine, 18(3), pp. 263-281.

Dean, J. W. J. \& Evans, J. R. (1994), Total QualityManagement, Organisation and Strategy, SouthWestern College Pub, pp. 288.

Douglas, T. J., \& Judge Jr, W. Q. (2001). Total quality management implementation and competitive advantage: the role of structural control and exploration. Academy of Management Journal, 44(1), pp. 158-169.

Elsmore, P. (2017). Organisational Culture: Organisational Change? Organisational Change. Routledge, New York, pp. 262.

Eskildson, L. (1994). Improving the odds of TQMs success. Quality Progress, 27(4), pp. 61-63.

Gambi, L. D. N., Boer, H., Gerolamo, M. C., Jorgensen, F., \& Carpinetti, L. C. R. (2015). The relationship between organisational culture and quality techniques, and its impact on operational performance. International Journal of Operations \& Production Management, 35 (10), pp. 1460-1484.

Gimenez-Espin, J. A., Jimenez-Jimenez, D., \& MartinezCosta, M. (2013). Organizational culture for total quality management. Total Quality Management \& Business Excellence, 24(5-6), pp. 678-692.

Grant, A.M. and Hofmann, D.A., (2011). Outsourcing inspiration: The performance effects of ideological messages from leaders and beneficiaries. Organizational Behavior and Human Decision Processes, 116(2), pp. 173-187.

Haigh, M. and Brubaker, P. (2010), Examining how image restoration strategy impacts perceptions of corporate social responsibility, organization-public relationships, and source credibility, Corporate Communications: An International Journal, 15 (4), pp. 453-468.
Hamilton, B. H., Nickerson, J. A., \& Owan, H. (2003). Team incentives and worker heterogeneity: An empirical analysis of the impact of teams on productivity and participation. Journal of Political Economy, 111(3), pp. 465-497.

Harari, O. (1993). Ten reasons why TQM doesn't work. Management Review, 82 (1), pp. 33-38.

Hatane, S.E., (2015). Employee satisfaction and performance as intervening variables of learning organization on financial performance. ProcediaSocial and Behavioral Sciences, 211, pp. 619-628.

House, R. J., and Javidan, M., (2004). Overview of GLOBE, In Culture, leadership, and organizations: The GLOBE study of 62 societies, House, R. J., Hanges, P. J., Javidan, M., Dorfman, P. W., \& Gupta, V. (Eds.), Sage publications, London, UK, pp. 9-28.

Hubbell, A. P., \& Chory-Assad, R. M. (2005). Motivating factors: Perceptions of justice and their relationship with managerial and organizational trust. Communication Studies, 56(1), 47-70.

Ilies, L., Salagean, H. C., and Beleiu, I. (2017). The impact of quality culture and leadership on customer relationship in organizations from the Romanian metal construction industry. Amfiteatru Economic, 19(11), pp. 1050-1063.

Irani, Z., Beskese, A. and Love, P.E.D., (2004). Total quality management and corporate culture: constructs of organisational excellence. Technovation, 24(8), pp. 643-650.

Ismiyarto; Suwitri, Sri; Warella, Y.; Sundarso, (2015). Organizational Culture, Motivation, Job Satisfaction and Performance of Employees toward the Implementation of Internal Bureaucracy Reform in the Ministry for the Empowerment of State Apparatus and Bureaucracy Reform (The Ministry of PANRB). Journal of Management and Sustainability, 5(1), pp. 192-199.

Javed, T. (2018). Impact of employee ownership on an organizational productivity: A mediating role of psychological ownership. Academy of Accounting and Financial Studies Journal, 22(2), pp. 1-12.

Kaluarachchi, K. A. S. P. (2010). Organizational culture and total quality management practices: a Sri Lankan case. The TQM Journal, 22(1), pp. 41-55.

Kim, K.Y. and Patel, P.C. (2017). Employee ownership and firm performance: A variance decomposition analysis of European firms. Journal of Business Research, 70, pp. $248-254$

Kristianto, P.B. and Rivai, A., (2018). The Influence of Leadership Style and Organizational Climate on Employee Performance through Organizational Commitment on Perum Pegadaian Branch East Bekasi. International Journal of Business and Applied Social Science, 4(6), pp. 34-51.

Kuchinke, K. P. (1998). The influence of leadership styles on subordinates' attitudes towards their leaders and towards performance: A comparison of US and German manufacturing employees. Human Resource Development International, 1(3), pp. 291-308. 
Lincoln, J. R., \& Kalleberg, A. L. (1996). Commitment, quits, and work organization in Japanese and US plants. ILR Review, 50(1), pp. 39-59.

Lo, M.C., Abang Azlan, M., Ramayah, T. and Wang, Y.C., (2015). Examining the effects of leadership, market orientation and leader member exchange (LMX) on organisational performance. Engineering Economics, 26(4), pp. 409-421.

McCroskey, L., Richmond, V., \& McCroskey, J. (2002). The scholarship of teaching and learning: Contributions from the discipline of communication. Communication Education, 51(4), pp. 383-391.

Moran, R. T., Abramson, N. R., \& Moran, S. V. (2014). Managing cultural differences. 9th edition, Routledge, NY, pp. 172.

Nasab, S., Hemmati, Y., \& Kia, S. (2014). An investigation on how TQM influences employee performance: A case study of banking industry. Management Science Letters, 4(1), pp. 31-36.

Flynn, B. B., Schroeder, R. G., \& Sakakibara, S. (1994). A framework for quality management research and an associated measurement instrument. Journal of Operations Management, 11(4), pp. 339-366.

Nordbäck, E. S., Myers, K. K., and McPhee, R. D. (2017). Workplace flexibility and communication flows: a structurational view. Journal of Applied Communication Research, 45(4), pp. 397-412.

O'Boyle, E.H., Patel, P.C. and Gonzalez-Mulé, E., (2016). Employee ownership and firm performance: a metaanalysis. Human Resource Management Journal, 26(4), pp. 425-448.

Oversmith, G. E. (1990). Developing employee ownership of the quality improvement process. Hospital materiel management quarterly, 12(1), pp. 38-45.

Paauwe, J. (2004). HRM and performance: Achieving longterm viability. Oxford University Press on Demand, Oxford.

Petliushenko, K., Kumar, V., Zwiegelaar, J., Loonam, J., \& Garza-Reyes, J. A. (2018). Investigating the benefits and challenges of Total Quality Management implementation in the pharmaceutical companies, British Academy of Management (BAM 2018) conference, Bristol, UK, September 2018, pp. 4-6

Pierce, J. L., Rubenfeld, S. A., \& Morgan, S. (1991). Employee ownership: A conceptual model of process and effects. Academy of Management Review, 16(1), pp. 121-144.

Rad, A. M. M. (2006). The impact of organizational culture on the successful implementation of total quality management. TQM Journal, 18(6), pp. 606-625.

Roldán, J.L., Leal-Rodríguez, A.L. and Leal, A.G., (2012). The influence of organisational culture on the Total Quality Management programme performance. Investigaciones Europeas de Dirección y Economía de la Empresa, 18(3), pp. 183-189.

Sabella, A., Kashou, R. and Omran, O., (2014). Quality management practices and their relationship to organizational performance. International Journal of Operations \& Production Management, 34(12), pp. 1487-1505.
Sengupta, S., Whitfield, K., \& McNabb, B. (2007). Employee share ownership and performance: golden path or golden handcuffs?. The International Journal of Human Resource Management, 18(8), pp. 15071538.

Shenawy, E., Baker, T., \& Lemak, D. J. (2007). A metalanalysis of the effect of TQM on competitive advantage. International Journal of Quality \& Reliability Management, 24 (5), pp. 442-471

Smith, S., Tranfield, D., Foster, M., \& Whittle, S. (1994). Strategies for Managing the TQ Agenda. International Journal of Operations \& Production Management, 14(1), pp. 75-88.

Stanić, L., Miklošević, I., and Glavaš, J. (2017). An analysis of teamwork in the insurance companies. Ekonomski vjesnik/Econviews-Review of Contemporary Business, Entrepreneurship and Economic Issues, 30(1), pp. 129-140.

Steers, R. M., \& Lee, T. W. (2017). Facilitating effective performance appraisals: The role of employee commitment and organizational climate. In Performance measurement and theory Routledge, pp. 75-93

Tejaningrum, A., (2016). Quality Culture and Capabilities Process Supply Chain of SMEs. International Journal of Organizational Innovation, 9(2), pp. 214-225

Tejaningrum, A., Azis, A.M. and Irjayanti, M., (2016). Quality Culture Model for SMEs, Actual Problems of Economics, 4(178), pp. 265-273

Tena, A. B. E., Llusar, J. C. B., \& Puig, V. R. (2001). Measuring the relationship between total quality management and sustainable competitive advantage: A resource-based view. Total Quality Management, 12(7-8), pp. 932-938.

Trought, B. (1995), Organisational culture: its importance to manufacturing technology, Advances in Manufacturing Technology 9 - Proceedings of the 11th National Conference on Manufacturing Research, Taylor \& Francis, London, pp. 539-546.

Vivas-López, S., (2014). Talent management and teamwork interaction: Evidence in large Spanish companies. International Journal of Business, 19(1), pp. 30-43

Weitzman, M. L., \& Kruse, D. L. (1990). Profit sharing and productivity, in "Paying for Productivity: A Look at the Evidence" (Alan Blinder, Ed.). Brookings Institution, Washington, DC.

Wilson, N., Cable, J. R., \& Peel, M. J. (1990). Quit rates and the impact of participation, profit-sharing and unionization: Empirical evidence from UK engineering firms. British Journal of Industrial Relations, 28(2), pp. 197-213.

Worthington, A. K., NussBaum, J. F., \& Parrott, R. L. (2015). Organizational credibility: The role of issue involvement, value-relevant involvement, elaboration, author credibility, message quality, and message effectiveness in persuasive messages from public health advocacy organizations. Communication Research Reports, 32(3), pp. 199-207. 
Vikas Kumar is a Professor of Operations and Supply Chain Management and Director of Research at Bristol Business School, University of the West of England, UK. He is also a Visiting Professor at Faculty of Accounting, Ton Duc Thang University, Ho Chi Minh City, Vietnam. He holds a PhD degree in Management Studies from University of Exeter, UK. He has published more than 180 peer-reviewed articles in leading International journals and International conferences including the Journal of Business Research, International Journal of Production Research, Supply Chain Management: an International Journal, Expert System with Applications, International Journal of Production Economics, and Production Planning \& Control. He serves on the editorial board of a number of international journals and has successfully secured funding in the excess of $£ 1$ million from various research agencies such as EPSRC, Innovate UK, British Academy, Newton Fund and British Council. His current research interests include Operational Excellence, Sustainability, Circular Economy, Food Supply Chains, and Industry 4.0.

Yu Han is associated with sales management and international trade industry. She holds a Master's degree in International Trade, Strategy, and Operations from University of Warwick. She has obtained Bachelor's degree in Japanese, studying foreign enterprises in her undergraduate thesis. Her research interests include organizational performance, culture of quality and quality management.

Ngân Tuyết Trương is a PhD Candidate, and a Research Assistant at the School of Business and Management, RMIT University, Vietnam. She takes research on Service Innovation, Service Quality, Operation and Supply Chain Management. Her research focuses on Customer Satisfaction and Customer Behaviours in Tourism and Hospitality industry.

Y Nhu Ngoc Hoang is a Lecturer at International Business and Marketing School, University of Economics Ho Chi Minh city, Vietnam. She teaches variety of subjects including Multinational Financial Management, Business and Enterprise, and International Logistics. She achieved both Bachelor of Arts (Honours) degree in Business Studies with Accounting and Finance, and Master's of Science degree in International Management at University of the West of England, UK. She is interested in the topics of retailing services (especially in developing countries), with the aim to improve not only local retailers' competitiveness within the globalization context, but also citizen's living standards via products and services with advanced quality.

Arvind Upadhyay is a Senior Lecturer in Operations, Logistics and Supply Chain Management at Brighton Business School, University of Brighton, UK. Dr Upadhyay combines a sound technical base across all aspects of operations, logistics and supply chain management with excellent communication skills, delivering knowledge, understanding and skills in a userfriendly, relevant manner. He has teaching experience across Doctoral, Masters and Undergraduate levels and on vocational and professional courses. His teaching, research and consulting stretches across the management spectrum, with an emphasis on integrating operations and supply chain with other management subject areas. 